\title{
KARAKTERISASI DAN MODIFIKASI KARBON AKTIF TEMPURUNG KELAPA SAWIT DENGAN ASAM NITRAT UNTUK MENJERAP LOGAM BESI DAN TEMBAGA DALAM MINYAK NILAM
}

\author{
Retno Harti ${ }^{1 a}$, Allwar ${ }^{2 a}$, Noor Fitri ${ }^{3 a}$ \\ ${ }^{\mathrm{a}}$ Program Studi Ilmu Kimia, FMIPA, Universitas Islam Indonesia \\ Jl. Kaliurang KM 14,5 Sleman Yogyakarta 55584 \\ 1retno_rei@yahoo.com \\ 2allwar@fmipa.uii.ac.id \\ 3nfitri1@gmail.com
}

\begin{abstract}
Modification of activated carbon has been conducted using nitric acid $\left(\mathrm{HNO}_{3}\right)$. Characterization unmodified and modified activated carbon follow type I of nitrogen adsorption isotherm showed microporous material. Langmuir surface area of 253,6 m/2 $/ \mathrm{g}$ to $491,6 \mathrm{~m}^{2} / \mathrm{g}$. Identification of fungtional groups by fourier transform infrared spectrometer and Boehm titration. An increasing oxygen group on phenol of 0,0399 meq/g to 0,1987 meq/g showed acid character.

Unmodified and modified activated carbon by nitric acid used as an adsorbent. The activated carbon to adsorp metal applied Fe and $\mathrm{Cu}$ in Patchouli oil. The metal testing by flame atomic absorption spectrophotometer. Maximum capacity of Fe sorption in unmodified activated carbon is 9,01 ppm/g and modified activated carbon is 12,16 ppm/g Maximum capacity of $\mathrm{Cu}$ sorption in unmodified activated carbon is 2,25 ppm/g and modified activated carbon is 2,85 $\mathrm{ppm} / \mathrm{g}$.
\end{abstract}

Keywords : Modified activated carbon, Surface area , Boehm titration, Patchouli oil, AAS

\section{PENDAHULUAN}

Karbon banyak ditemukan di kehidupan sehari-hari dan jumlahnya cukup banyak. Karbon memiliki bentuk amorf dan banyak ditemukan dari berbagai bahan utama, antara lain batubara, tempurung kelapa, limbah industri, kayu, biji aprikot, kulit singkong, dan kulit kemiri. Cara penggunaan karbon yaitu dengan aktivasi. Karbon aktif memiliki daya serap tinggi karena memiliki volume pori yang dapat menyerap gas maupun residu dalam larutan.

Meningkatnya penggunaan karbon aktif menumbuhkan kreativitas untuk memaksimalkan fungsi karbon, bukan hanya dari luas permukaan dan pori-porinya saja tetapi pada permukaan karbonnya juga. Proses modifikasi permukaan karbon ada beberapa larutan oksidator yang pernah digunakan dalam penelitian seperti $\mathrm{H}_{2} \mathrm{O}_{2}, \mathrm{NaOCl}$, $\left(\mathrm{NH}_{4}\right) \mathrm{S}_{2} \mathrm{O}_{8}, \mathrm{AgNO}_{3}, \mathrm{HNO}_{3}$ dan $\mathrm{H}_{2} \mathrm{SO}_{4}$ (Wibowo, dkk, 2004). Selain itu, penelitian menggunakan tetra butil ammonium iodida (TBAI) dan natrium dietil dithiokarbamat (SDDC) (Moser dan Adhoum, 2002).

Modifikasi permukaan karbon aktif dilakukan untuk menambah gugus aktif. Gugus aktif yang akan ditambah merupakan gugus oksigen. Gugus-gugus aktif pada permukaan karbon menghilang pada waktu pembuatan karbon aktif. Hal itu terjadi karena pada saat pembuatan 
karbon aktif menggunakan temperatur yang tinggi sehingga mengakibatkan gugus-gugus aktif terlepas dan tersisa karbon.

Minyak nilam merupakan salah satu minyak atsiri yang diperoleh dengan cara penyulingan dari tanaman nilam. Namun dalam proses pembuatan minyak nilam ada beberapa yang memperoleh minyak nilam tidak pada kondisi yang diinginkan. Minyak dengan kualitas buruk akan terlihat pada tingkat kejernihan minyak yang terjadi karena adanya kontaminasi. Alat suling tradisional dengan tangki bekas drum minyak menjadi salah satu penyebab, dimana ion logam seperti magnesium, besi, mangan, tembaga, plumbum, dan seng dapat terlarut di dalam minyak. Biasanya minyak yang dihasilkan akan terlihat lebih gelap dan berwarna kehitaman atau sedikit kehijauan akibat kontaminasi dari logam besi (Fe) dan tembaga (Cu) (Sariadi, 2012).

Pemurnian minyak nilam menjadi sangat penting karena perubahan warna yang terjadi akibat logam besi dan tembaga menurunkan mutu minyak nilam. Akibatnya harga minyak nilam dengan kualitas buruk akan turun dari standar harga pasar. Hal ini dapat merugikan penyuling karena ketidaksesuaian pendapatan dan pengeluaran.

Pada penelitian ini akan dipelajari pengaruh penambahan larutan $\mathrm{HNO}_{3}$ kedalam karbon aktif. Karbon aktif yang akan dipakai hanya satu jenis saja. Karbon yang didapat kemudian diaplikasikan untuk menjerap logam besi dan logam tembaga pada minyak nilam. Selain itu penggunaan karbon aktif sebagai pemurni logam besi dan tembaga pada minyak nilam belum ada yang pernah menuliskan.

\section{TUJUAN PENELITIAN}

1. Menambah gugus fungsi asam pada karbon aktif.

2. Mengetahui banyaknya logam $\mathrm{Fe}$ dan Cu yang terjerap pada karbon aktif yang telah dimodifikasi permukaannya dalam minyak nilam.

3. Mengetahui ada atau tidaknya perbedaan banyaknya logam Fe dan $\mathrm{Cu}$ yang terjerap pada karbon aktif yang non modifikasi maupun modifikasi permukaannya dalam minyak nilam.

\section{METODE PENELITIAN}

\section{Alat}

Seperangkat Alat Gelas pyrex dan herma, Furnace Vulcan, Cawan Porselen, Refluks Stahl, Oven Memmert, Kompor Listrik, Magnetic Stirrer Labinco, Neraca Analitik Sartorius, Refraktometer Atago, Piknometer $5 \mathrm{~mL}$ pyrex, Fourier Transform Infrared Spectroscopy (FTIR) Shimadzu, Atomic Absorption Spectroscopy (AAS) Perkin-Elmer Zeemen, Scanning Electron Microscope (SEM), dan Surface Area Analyzer (SAA) Quantachrome

\section{Bahan}

Karbon aktif, $\mathrm{HNO}_{3}$ pekat, Akuades, $\mathrm{NaHCO}_{3}, \mathrm{Na}_{2} \mathrm{CO}_{3}, \mathrm{NaOH}$, $\mathrm{HCl}, \quad \mathrm{Na}_{2} \mathrm{~B}_{4} \mathrm{O}_{7}, \quad \mathrm{H}_{2} \mathrm{C}_{2} \mathrm{O}_{4}, \quad$ Indikator phenolphthalein, Indikator metilen merah, Kertas pH, Fe 1000 ppm, Cu 1000 ppm, Kertas saring wathman 42, Kertas saring biasa, Etanol, $\mathrm{KOH}$, Aluminium foil, dan Minyak nilam.

\section{Prosedur Penelitian}

\section{A. Modifikasi Karbon Aktif}

Sebanyak 50 gram karbon aktif ditambah $\mathrm{HNO}_{3} 10 \mathrm{~N}$ dan direfluks 
selama 6 jam. Dicuci hingga $\mathrm{pH}$ 6-7 dengan bantuan $\mathrm{NaOH}$. Dikeringkan ke dalam oven $110^{\circ} \mathrm{C}$ selama 2 jam dan difurnes pada suhu $300^{\circ} \mathrm{C}$ selama 2 jam.

\section{B. Karakterisasi Karbon Aktif}

Karakterisasi menggunakan instrumen Surface Area Analyzer (SAA), Fourier Transform Infrared Spectroscopy (FTIR), Scanning Electron Microscope (SEM) dan titrasi Boehm. SAA untuk mengetahui isoterm linear, luas permukaan dan volume pori karbon aktif. FTIR untuk mengetahui gugus fungsi pada permukaan karbon aktif. SEM untuk mengetahui morfologi dan EDX karbon aktif. Sedangkan titrasi Boehm untuk mengetahui jumlah gugus asam dan basa pada permukaan karbon aktif.

Analisis gugus asam dilakukan dengan merendam 0,5 gram karbon aktif menggunakan analit $\mathrm{NaHCO}_{3} 0,5 \mathrm{~N}$, $\mathrm{Na}_{2} \mathrm{CO}_{3}$ 0,5 $\mathrm{N}$ dan $\mathrm{NaOH} 0,5 \mathrm{~N}$ masingmasing sebanyak $50 \mathrm{~mL}$. Didiamkan selama 24 jam dan disaring. Analit tersebut di titrasi menggunakan $\mathrm{HCl} 0,5$ $\mathrm{N}$ yang telah distandarisasi dengan $\mathrm{Na}_{2} \mathrm{~B}_{4} \mathrm{O}_{7}$.

Analisis gugus basa dilakukan dengan merendam 0,5 gram karbon aktif menggunakan analit $\mathrm{NaOH} \quad 0,5 \quad \mathrm{~N}$ sebanyak $50 \mathrm{~mL}$. Didiamkan selama 24 jam dan disaring. Analit tersebut di titrasi menggunakan $\mathrm{NaOH} 0,5 \mathrm{~N}$ yang telah distandarisasi dengan $\mathrm{H}_{2} \mathrm{C}_{2} \mathrm{O}_{4}$.

\section{Aplikasi Karbon Aktif}

Karbon aktif dengan variasi berat sebanyak 1 gram, 2 gram, 3 gram dan 4 gram. Dimasukkan ke dalam gelas beker dan ditambah $50 \mathrm{~mL}$ minyak nilam. Diaduk selama 24 jam dan disaring. Hasil minyak nilam dianalisis dengan AAS untuk mengetahui kandungan $\mathrm{Fe}$ dan $\mathrm{Cu}$. Untuk mengetahui kualitas minyak nilam lainnya dilihat warna serta dihitung bobot jenis, bilangan asam dan indeks bias.

Analisis kandungan $\mathrm{Fe}$ dengan menimbang minyak nilam sebanyak 0,5 gram (untuk $\mathrm{Fe}$ ) dan 1,5 gram (untuk $\mathrm{Cu}$ ). Minyak nilam difurnes dengan suhu $800^{\circ} \mathrm{C}$ selama 2 jam. Ditambah $\mathrm{HNO}_{3}$ pekat dan dipanaskan hingga larut sempurna. Didinginkan dan ditambah 10 $\mathrm{mL}$ akuades. Disaring dengan kertas saring wathman. Filtrat dianalisis menggunakan AAS beserta standar Fe dan $\mathrm{Cu}$ dengan berbagai konsentrasi.

\section{PEMBAHASAN}

\section{Karakterisasi Karbon Aktif}

\section{A. Isoterm Linear}

Isoterm linear karbon aktif (Gambar 1) mengikuti tipe I berdasarkan IUPAC tentang variasi bentuk isoterm gas. Selain itu, grafik isoterm linear membentuk tunggal adsorpsi (monolayer adsorption). Monolayer adsorption memberikan gambaran bahwa terjadi interaksi kuat secara kemisorpsi antara adsorben dengan adsorbat. Adsorpsi tipe I berlaku untuk material mikropori. Perbedaan lain yang terlihat yaitu titik antara karbon aktif modifikasi dengan non modifikasi asam nitrat. Terlihat bahwa volume karbon aktif modifikasi lebih tinggi dibandingkan karbon aktif non modifikasi. Hal ini kemungkinan karena penambahan volume pori-pori.

\section{B. Luas Permukaan}

Data SAA pada tabel 1 menunjukkan kenaikan luas permukaan Langmuir dari karbon aktif non modifikasi dengan modifikasi asam nitrat yaitu $253,6 \mathrm{~m}^{2} / \mathrm{g}$ menjadi $491,6 \mathrm{~m}^{2} / \mathrm{g}$. Penambahan luas permukaan tersebut disebabkan oleh asam nitrat pada saat modifikasi. Asam nitrat dengan bantuan 
pemanasan melarutkan pengotor pada karbon aktif sehingga karbon aktif menjadi bersih.

\section{Gugus Fungsi}

Hasil spektra FTIR menunjukkan perbedaan serapan gugus fungsi pada karbon aktif modifikasi dan non modifikasi. Pada kedua spektra memiliki serapan dengan tipe yang sama, yaitu serapan hanya terjadi pada daerah

\section{Tabel 1. Data SAA}

\begin{tabular}{|l|c|c|}
\hline \multicolumn{1}{|c|}{ Karbon Aktif } & $\begin{array}{c}\text { Non } \\
\text { Modifikasi }\end{array}$ & Modifikasi \\
\hline $\begin{array}{l}\text { Luas } \\
\text { permukaan } \\
\text { BET (m²/g) }\end{array}$ & 164,2 & 325,4 \\
\hline $\begin{array}{l}\text { Luas } \\
\text { permukaan } \\
\text { Langmuir } \\
\left(\mathrm{m}^{2} / \mathrm{g}\right)\end{array}$ & 253,6 & 491,6 \\
\hline $\begin{array}{l}\text { DR Volume } \\
\text { mikropori } \\
(\text { cc/g) }\end{array}$ & 0,08995 & 0,1729 \\
\hline $\begin{array}{l}\text { Total volume } \\
\text { pori (P/Po }= \\
0.99)(c c / g)\end{array}$ & 0,1009 & 0,1863 \\
\hline $\begin{array}{l}\text { Rata-rata } \\
\text { diameter pori } \\
(\AA)\end{array}$ & 12,30 & 11,45 \\
\hline $\begin{array}{l}\text { DA diameter } \\
\text { pori }(\AA)\end{array}$ & 9,50 & 8,00 \\
\hline
\end{tabular}

\section{Titrasi Boehm}

Titrasi Boehm terdiri dari dua analisis yaitu analisis sifat asam dan analisis sifat basa. Berdasarkan tersebut. Semakin banyak gugus fungsi yang terserap maka intensitas \% transmisi akan semakin menurun. Penurunan tersebut berarti proses modifikasi tersebut mengakibatkan bertambahnya gugus fungsi. Selain itu, pada kedua karbon aktif menunjukkan serapan pada 2368,59 $\mathrm{cm}^{-1}$, yang merupakan serapan karbonil $(\mathrm{C}=\mathrm{O})$ dari $\mathrm{CO}_{2}$.

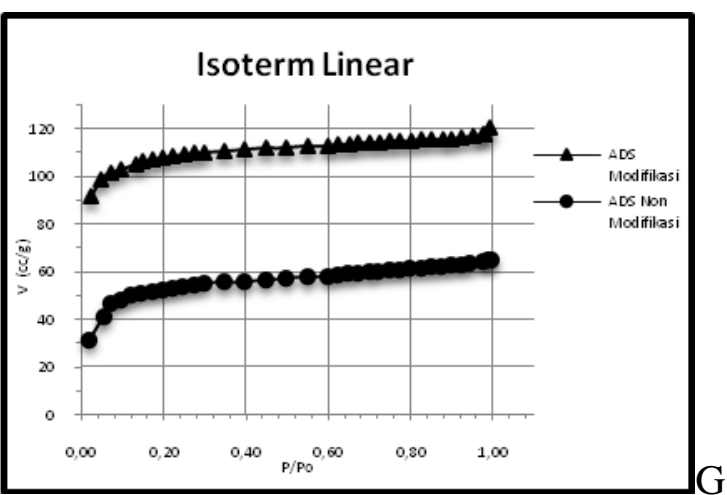

ambar 1. Isoterm linear karbon aktif

Tabel 2. Hasil Titrasi Boehm

\begin{tabular}{|c|c|c|c|c|c|}
\hline \multirow{2}{*}{ Karbon aktif } & \multicolumn{3}{|c|}{ Gugus asam (mek/g) } & \multirow{2}{*}{$\begin{array}{c}\text { Total gugus } \\
\text { asam (mek/g) }\end{array}$} & \multirow{2}{*}{$\begin{array}{c}\text { Total gugus } \\
\text { basa (mek/g) }\end{array}$} \\
\hline & Karboksil & Lakton & Fenol & & \\
\hline Non Modifikasi & 0,0200 & 0,0300 & 0,0399 & 0,0899 & 0,0700 \\
\hline Modifikasi & 0,0200 & 0,0300 & 0,1897 & 0,2397 & 0,0899 \\
\hline
\end{tabular}


Hasil titrasi Boehm pada tabel 2 menunjukkan adanya penambahan gugus fungsi asam. Gugus asam yang bertambah yaitu gugus fenol. Penambahan gugus fenol sesuai dengan hasil FTIR yang menunjukkan bahwa terdapat serapan dan penurunan intensitas pada gugus aromatik dan hidroksil. Gugus fenol yang bertambah yaitu dari 0,0399 mek/g menjadi 0,1897 mek/g menunjukkan bertambahnya gugus oksigen. Sedangkan pada gugus karboksil dan lakton tidak terlihat pada spektra FTIR dikarenakan jumlah gugus tersebut terlalu kecil sehingga tidak dapat terdeteksi. Dari hasil yang didapatkan, pada permukaan karbon aktif lebih bersifat asam.

\section{E. Morfologi Karbon Aktif}

Morfologi permukaan karbon aktif modifikasi dengan non modifikasi memiliki perbedaan. Pada karbon aktif non modifikasi diketahui terdapat poripori tetapi tidak rata dan tidak bersih dibandingkan karbon aktif modifikasi. Hal tersebut kemungkinan karena pengotor yang masih terdapat pada permukaannya. Pada karbon aktif modifikasi asam nitrat pori-pori terlihat lebih bersih dan rata. Hal tersebut diasumsikan bahwa pengotor telah hilang karena perlakuan menggunakan asam nitrat pada saat modifikasi dan pemanasan.

Selain morfologi permukaan didapatkan data EDX permukaan karbon aktif. Pada karbon aktif non modifikasi, unsur $\mathrm{Fe}$ dan $\mathrm{Cu}$ terdapat sebesar 0,96\% dan 1,32\%. Sedangkan pada karbon aktif modifikasi asam nirat hanya terdapat unsur $\mathrm{Cu}$ yang telah menurun menjadi 0,21\%. Keberadaan $\mathrm{Fe}$ dan $\mathrm{Cu}$ pada karbon aktif ini memungkinkan mengurangi kemampuan penjerapan.

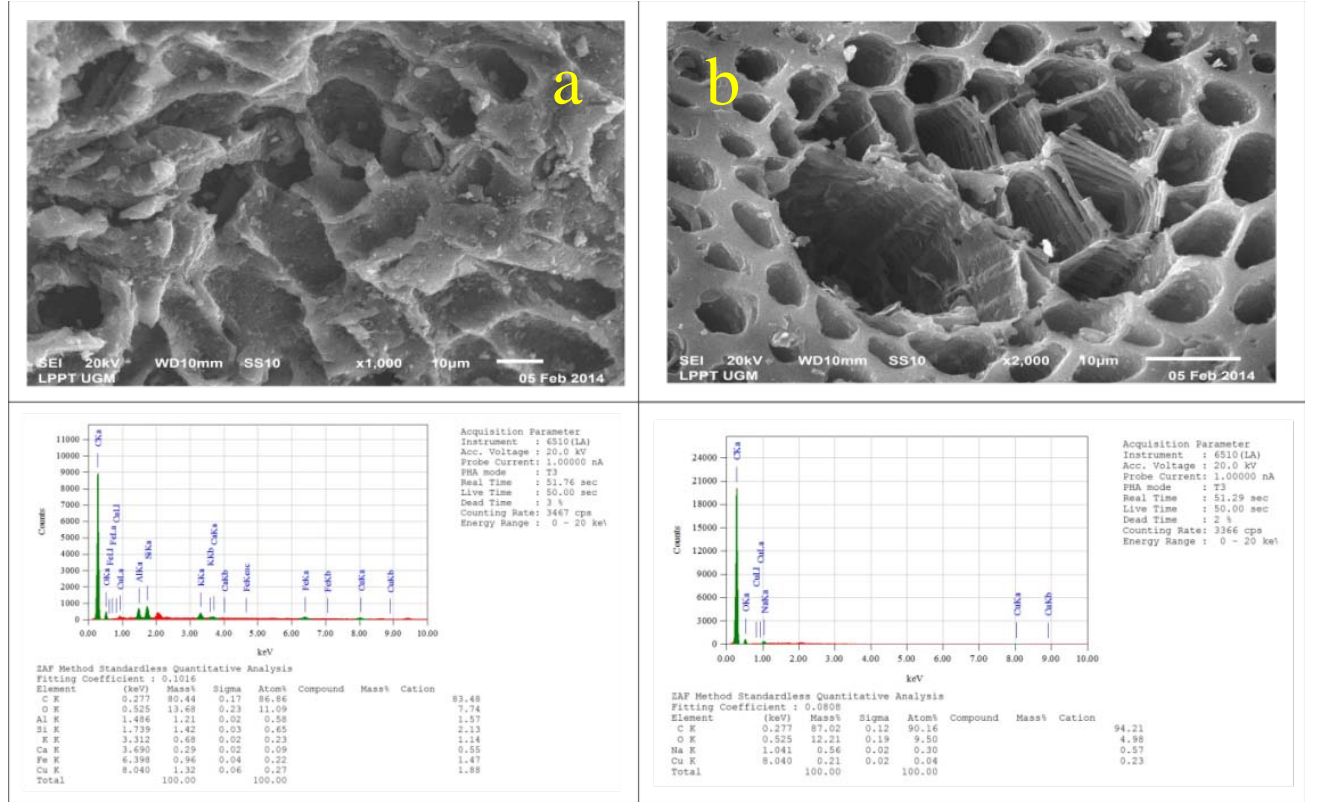

Gambar 2. Morfologi dan EDX karbon aktif a) non modifikasi b) modifikasi 


\section{Aplikasi Karbon Aktif}

\section{A. Kandungan Fe}

Kadar Fe pada minyak nilam dilakukan dengan menggunakan AAS. SNI 06-2385-2006 mensyaratkan kandungan Fe maksimal adalah 25 $\mathrm{mg} / \mathrm{kg}$. Pada penelitian ini diperoleh data pada tabel 3. Kualitas minyak nilam awal tidak memenuhi standar Fe sesuai SNI 06-2385-2006 karena memiliki kandungan Fe sebesar 47,44 mg/kg. Penggunaan variasi berat karbon aktif dilakukan untuk melihat kapasitas jerapan tertinggi logam Fe pada karbon aktif.

Kapasitas jerapan Fe terbanyak dengan menggunakan karbon aktif modifikasi yang mencapai $12,16 \mathrm{ppm} / \mathrm{g}$. Sesuai data FTIR dan titrasi Boehm hal ini dapat disebabkan karena bertambahnya gugus fungsi oksigen pada permukaan karbon aktif modifikasi. Penambahan gugus fungsi tersebut mengoptimalkan Fe terjerap pada karbon aktif. Selain itu, penambahan luas permukaan karbon aktif modifikasi menghasilkan interaksi yang semakin banyak pada permukaannya. Oleh sebab itu, semakin banyak Fe yang terjerap oleh karbon aktif modifikasi. Hasil tersebut menunjukkan bahwa karbon aktif modifikasi asam nitrat memiliki daya adsorpsi logam yang lebih baik dibandingkan karbon aktif non modifikasi. Sehingga dapat disimpulkan bahwa kapasitas karbon aktif modifikasi lebih efektif untuk menyerap logam Fe sebesar 12,16 ppm/g yaitu pada massa 2,00 gram. Selain itu, kapasitas jerapan karbon aktif non modifikasi terbesar yaitu 9,01 ppm/g pada massa 3,00 gram.

\section{B. Kandungan $\mathrm{Cu}$}

Terdapat perbedaan daya serap logam $\mathrm{Cu}$ pada karbon aktif modifikasi dan non modifikasi. Karbon aktif non modifikasi lebih rendah dibandingkan karbon aktif modifikasi. Karbon aktif non modifikasi secara konstan menjerap $\mathrm{Cu}$ dimulai dari 2 gram. Pada penjerapan dengan massa karbon aktif 1 gram menghasilkan kenaikan kandungan $\mathrm{Cu}$. Hal ini kemungkinan disebabkan karena lepasnya $\mathrm{Cu}$ dari karbon aktif. Kandungan $\mathrm{Cu}$ pada karbon aktif sesuai dengan data EDX sebesar 1,32\%.

Pada karbon aktif modifikasi penurunan $\mathrm{Cu}$ berbanding lurus dengan massa. Semakin banyak karbon aktif semakin banyak $\mathrm{Cu}$ yang terjerap. Kecuali pada karbon aktif dengan massa 4 gram. Kandungan $\mathrm{Cu}$ pada massa 4 gram sedikit mengalami kenaikan dari massa 3 gram yaitu 2,36 mg/kg menjadi $2,60 \mathrm{mg} / \mathrm{kg}$. Hal ini kemungkinan karena karbon aktif lebih banyak menjerap Fe sehingga tidak maksimal saat menjerap Cu. Namun, karbon aktif modifikasi lebih efektif untuk menjerap $\mathrm{Cu}$ dibandingkan karbon aktif awal. Kapasitas jerapan Cu terbesar pada karbon aktif non modifikasi sebesar 2,25 ppm/g pada massa 3,00 gram. Kapasitas jerapan terbesar pada karbon aktif modifikasi sebesar 2,85 $\mathrm{ppm} / \mathrm{g}$ pada massa yang sama yaitu 3,00 gram.

\section{Kualitas Minyak Nilam}

Uji kualitas minyak nilam antara lain warna, indeks bias, bobot jenis, dan bilangan asam menghasilkan data yang tidak jauh beda pada minyak nilam sampel. Sehingga dapat disimpulkan bahwa karbon aktif tidak berpengaruh pada uji tersebut. 


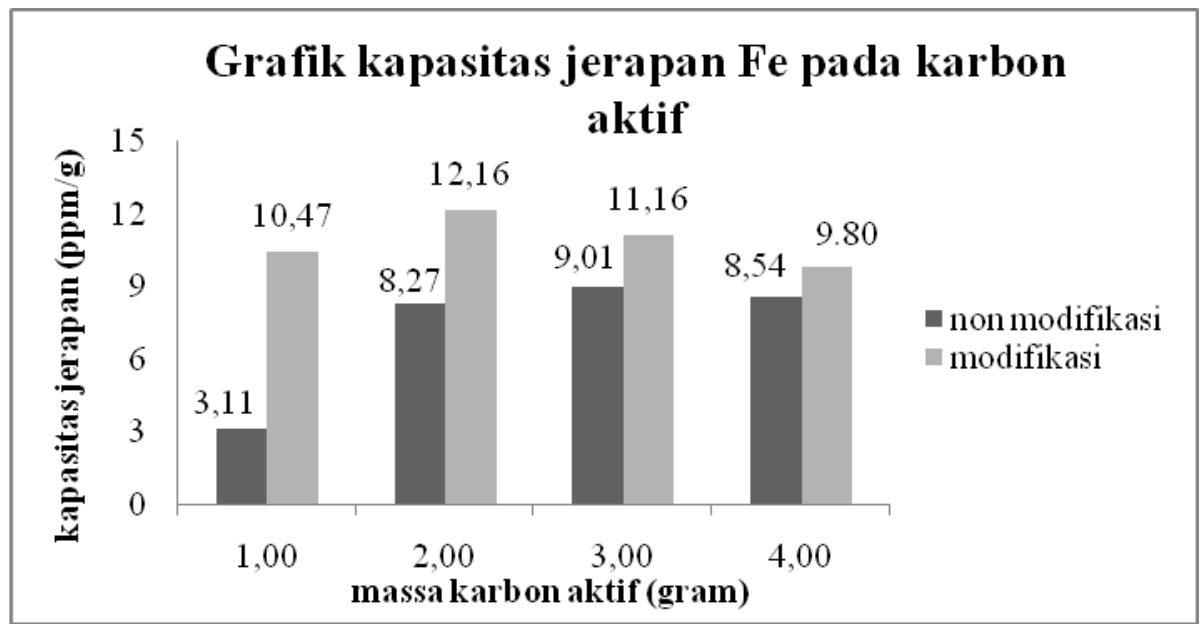

Gambar 3. Kapasitas jerapan Fe pada karbon aktif

Tabel 4 : Kapasitas Jerapan Cu Pada Karbon Aktif

\begin{tabular}{|c|c|c|c|c|}
\hline $\begin{array}{c}\text { Kandungan } \\
\text { Cu sampel } \\
\text { (mg/kg) }\end{array}$ & Karbon aktif & $\begin{array}{l}\text { massa } \\
\text { karbon } \\
\text { (gram) }\end{array}$ & $\begin{array}{c}\text { Kandungan } \\
\text { Cu } \\
\text { (mg/kg) }\end{array}$ & $\begin{array}{c}\text { Kapasitas } \\
\text { jerapan } \\
\text { (ppm/g) }\end{array}$ \\
\hline \multirow{8}{*}{10,90} & \multirow{4}{*}{$\begin{array}{c}\text { Non } \\
\text { modifikasi }\end{array}$} & 1,00 & 19,25 & $-8,35$ \\
\hline & & 2,00 & 10,70 & 0,10 \\
\hline & & 3,00 & 4,15 & 2,25 \\
\hline & & 4,00 & 4,00 & 1,73 \\
\hline & \multirow{4}{*}{ Modifikasi } & 1,00 & 10,67 & 0,23 \\
\hline & & 2,00 & 6,12 & 2,39 \\
\hline & & 3,00 & 2,36 & 2,85 \\
\hline & & 4,00 & 2,60 & 2,08 \\
\hline
\end{tabular}

\section{KESIMPULAN}

1. Modifikasi karbon aktif menggunakan asam nitrat menghasilkan penambahan luas permukaan Langmuir dari 253,6 $\mathrm{m}^{2} / \mathrm{g}$ menjadi $491.6 \mathrm{~m}^{2} / \mathrm{g}$ dan gugus asam fenol dari 0,0399 menjadi $0,1897 \mathrm{mek} / \mathrm{g}$.

2. Kapasitas jerapan Fe maksimal menggunakan karbon aktif non modifikasi mencapai 9,01 ppm/g, sedangkan karbon aktif modifikasi asam nitrat mencapai 12,16 ppm/g.

3. Kapasitas jerapan $\mathrm{Cu}$ maksimal menggunakan karbon aktif non modifikasi mencapai 2,25 ppm/g, sedangkan karbon aktif modifikasi asam nitrat mencapai 2,85 ppm/g.

4. Uji kualitatif minyak nilam antara lain warna, indeks bias, bobot jenis dan bilangan asam tidak berpengaruh secara signifikan. 


\section{DAFTAR PUSTAKA}

Abassi, W. A. and Streat, M. 1994. Adsorbtion of uranium from aqueous solution using activated carbon. Separ. Sci. Technol. 29:1217-1225.

Abdullah, A. H., Yuan, W. W., and Yaziz, M. I. 2010. Decolorisation of reactive orange 16 by activated carbon and copper oxide catalysts suported by activated carbon. J. Phys. Sci. Vol. 2 (2) : $29-40$.

Anggraeni, N. D. 2008. Analisa SEM (Scanning Electron Microscopy) dalam pemantauan proses oksidasi magnetite menjadi hematite. Seminar Nasional Teknik Mesin, Rekayasa dan Aplikasi Teknik Mesin Di Industri : 50-56. ISSN 1693-3168.

Anonim,. - . Scanning Electron Microscope. http://www.purdue. edu/rem/rs/sem.html diakses 26 Februari 2014 .

Alfian. 2003. Analisis kadar logam besi (Fe) dari minyak nilam (patchouli oil) yang diperoleh dari penyulingan dengan menggunakan wadah kaca, stainless steel dan drum bekas secara spektrofotometri serapan atom. J. Chem. Sci. vol. 7, no. 2 : 55-58.

Allwar. 2012. Characteristics of pore structures and surface chemistry of activated carbons by physisorption, ftir and boehm methods. J. Appli. Chem. (IOSRJAC). Volume 2 : 2278-5736.

Apriliani, A., 2010, Pemanfaatan Arang Ampas Tebu Sebagai Adsorben Ion Logam Cd, Cr, Cu Dan Pb Dalam Air Limbah, Skripsi, Program Studi Kimia Fakultas Sains dan Teknologi Universitas Islam Negeri Syarif Hidayatullah Jakarta.

Atkins, P.W., 1997, Kimia Fisika, Jilid 2 edisi keempat, Erlangga., Jakarta.

Badan Standardisasi Nasional. 2006. Standar Nasional Indonesia: Minyak nilam. SNI 062385-2006. ICS 71.100.60.

Brahmana, H. R. 1991. Pengaruh pemanbahan minyak kruing dan besi oksida terhadap mutu minyak nilam (patchouli oil). Komunikasi Penelitian. 3 (4) : 330-341.

Companion, A. L., 1991., Ikatan Kimia, Penerbit ITB, Bandung.

Day, R. A. dan Underwood, A. L., 2002, Analisis Kimia Kuantitatif, Erlangga, Jakarta.

Fatimah, I., 2014, Adsorpsi dan Katalisis Menggunakan Material Berbasis Clay, Graha Ilmu, Jogjakarta.

Fessenden, R. J., dan Fessenden, J. S., 1997, Dasar-dasar Kimia Organik, Erlangga, Jakarta.

Fessenden, R. J., dan Fessenden, J. S., 1982, Kimia Organik, Edisi Ketiga Jilid 1, Erlangga, Jakarta.

Goncalves, M; Garcla, L. S; Jardim, E. O; dan Albero, J. S. 2011. Ammonia removal using activated carbons: effect of the surface chemistry in dry and moist conditions. Env. Sci. Technol.--

Guenther, E., 1990, Minyak Atsiri, Diterjemahkan oleh R.S. Ketaren dan R. Mulyono, Jilid IIIA, UI Press, Jakarta.

Gufta, F. K. 1998. Utilization of bagasse fly ash generated in the sugar industry for removal and recovery of phenol and p-nitrophenol from wastewater. J. Chem. Technol. Biotechnol. 70 : 180 - 186.

Hersanti, E. S. dan Ardiwinata, A. N., 2011, Arang Aktif Meningkatkan Kualitas Lingkungan, Sinartani : agroinovasi, Badan litbang pertanian edisi april, No.3400 tahun XLI. 
Ismadji, S. and Bhatia, S. K. 2001. Characterization of activated carbon using liquid phase adsorbtion. Carbon. 39:1237-1250.

Khopkar, S. M., 2008, Konsep Dasar Kimia Analitik, UI Press, Jakarta.

Ketaren, 1986, Pengantar Teknologi Minyak Atsiri, Balai Pustaka, Jakarta.

Ma'mun. 2008. Pemurnian minyak nilam dan minyak daun cengkeh secara kompleksometri. J. Litt. 14(1) : 36-42.

Marshall, W. E. dan Mitchell, M. J. 1996. Agriculture by-product as metal adsorbent : sorption properties and resistence to mechanical abrasion. J. Chem. Technol. Biotechnol. 66 : 92 - 198.

Merck. 2009. Lembar Data Keselamatan Bahan. www.merck-chemicals.com. diakses 1 april 2014.

Mikrajuddin, A., dan Khairurrijal. 2009. Karakterisasi nanomaterial. Review. J. nanosains. nanotekno. Vol 2 no. 1 : 1-9. ISSN 1979-0880.

Moser, L., and Adhoum, N. 2002. Modified activated carbon for the removal of copper, zinc, chromium and cyanide from wastewater. Sep. Purif. Technol. 26 : 137-146.

Nurul'ain, 2007, The Production and Characterization of Activated Carbon Using Local Agricultural Waste Though Chemical Activation Process, Tesis, School of Material and Mineral Engineering, Universiti Sains Malaysia, Malaysia

Petrucci, 1987. Kimia Dasar Prinsip dan Terapan Modern Edisi Keempat Jilid 2, Erlangga, Jakarta.

Rahmayani, F. 2009. Analisa Kadar Besi (Fe) dan Tembaga (Cu) dalam Air Zamzam secara spektrofotometri Serapan Atom (SSA). Karya Ilmiah, Program Studi Diploma III Kimia Analis, Fakultas Matematika dan Ilmu Pengetahuan Alam, Universitas Sumatera Utara, Sumatera Utara.

Rios, R. R. V. A; Alves, D. E; Dalmazio, I; and Fernando, S. 2003. Tailoring Activated Carbon by Surface chemical modification with $\mathrm{O}, \mathrm{S}$, and $\mathrm{N}$ containing molecules. Mater. Res. Vol 6, No 2 : 129-135.

Riyanto, 2009. Diktat Kuliah Kimia Analisis Instrumental 1, Hibah Pengajaran PHK-I 2008. Program Studi Ilmu Kimia Fakultas MIPA, Universitas Islam Indonesia, Yogyakarta.

Ros, T. G; Dillen, A. J; Gues, J. W; and Koningsberger, D. C. 2002. Surface oxidation of carbon nanofibres. Chem. Eur. J, 8, No.5: 1151-1162.

Rumidatul, A. 2006. Efektivitas Arang Aktif sebagai Adsorben pada Pengolahan Air Limbah, Tesis, Sekolah Pasca Sarjana, Institut Pertanian, Bogor.

Rusli, S. 2002. Diversifikasi ragam dan peningkatan mutu minyak atsiri. Makalah workshop nasional minyak atsiri. Deperindag. Jakarta. 13.

Sahroni, I., 2014, Membran Keramik Berbasis $\mathrm{TiO}_{2}$ dan Kaolin Sebagai Bahan Penurunan Kadar Fe, Mn, dan Mikroba Dalam Air, Skripsi, Program Studi Ilmu Kimia Fakultas Matematika dan Ilmu Pengetahuan Alam, Universitas Islam Indonesia, Yogyakarta.

Saito, T. diterjemahkan oleh Ismunandar., 1996., Buku Teks Kimia Anorganik Online, Iwanami Publishing Company, Tokyo.

Sari, L.N., 2014, Modifikasi Karbon Aktif dari Tempurung Kelapa Sawit dengan Amonia $\left(\mathrm{NH}_{3}\right)$, Karakterisasi dan Aplikasi pada Pemisahan Logam Fe dan Cu dalam Minyak Nilam, Skripsi, Program Studi Ilmu Kimia Fakultas Matematika dan Ilmu Pengetahuan Alam, Universitas Islam Indonesia, Yogyakarta. 
Sariadi. 2012. Pemurnian minyak nilam dengan proses adsorbs menggunakan bentonit. $J$. Tekno. vol. 12, no. 2 : $100-104$.

Sastrohamidjojo, H., 1992, Spektroskopi Inframerah, Liberty, Yogyakarta.

Sastrohamidjojo, H., 2011, Kimia Organik Dasar, UGM Press, Yogyakarta.

Silverstein, R. M., Webster, F. X., dan Kiemle, D. J., 2005, Spectrometric Identification of Organic Compounds, Seventh edition, John Wiley \& sons,inc, USA.

Siregar, D., 2009, Penggunaan Nano Kitosan Sebagai Penyalut Karbon Aktif untuk Menyerap Logam Stannum dengan Spektrofotometri Serapan Atom, Tesis, Sekolah Pascasarjana, Universitas Sumatera Utara, Medan.

Shen, W; Li, Z; dan Liu, Y. 2008. Surface chemical functional group modification of porous carbon. Recent Patents. Chem. Eng. I: 27 - 40.

Suhendra, D., dan Gunawan, E. R. 2010. Pembuatan arang aktif dari batang jagung menggunakan activator asam sulfat dan penggunaannya pada penjerapan ion tembaga (II). Makara, Sains.14 : 22-26.

Suhirman, S., 2010, Penggunaan Minyak Nilam dan Pemanfaatan Limbahnya, Laporan Penelitian, Balai Penelitian Tanaman Obat dan Aromaterapi, Bogor.

Sukardjo, 1985, Kimia Anorganik, Bina Aksara Yogyakarta.

Tang. 2004. Study of the CO2 Adsorption capacities of modified activated anthracites. Prepr. Pap.-Am. Chem. Soc., Div. Fuel Chem. 49 (1) : 308-309.

Wibowo, N., Setiawan, J., dan Ismadji, S. 2004. Modifikasi gugus aktif suatu karbon aktif dan karakterisasinya. J. Tek. Kim. Ind. 3 : 39-46.

Wirawan, T. dan Lestari, S. 2010 . Pemanfaatan arang aktif dari tempurung jarak pagar (Jatrophacurcas L.) yang termodifikasi untuk adsorpsi logam berat dari limbah cair. Seminar Nasional Peran Kimia dalam Pembangunan Agro-Industri dan Energy. ISBN 978-602-19421-0-9.

Ying, J. Y., Martinez, J.G., Lancaster, T. 2005. Porous Carbon Structures an Methods. US Patent. - .

Zaimah, S., 2013, Pengujian Kualitas dan Komposisi Kimia Minyak Nilam (Pogestemon cablin beth) setelah Penyimpanan, Skripsi, Program Studi Ilmu Kimia Fakultas Matematika dan Ilmu Pengetahuan Alam, Universitas Islam Indonesia, Yogyakarta. 